\title{
PENGARUH MODEL PEMBELAJARAN PROBLEM BASED LEARNING TERHADAP HASIL BELAJAR SISTEM INSTALASI REFRIGERASI
}

\author{
Andre Ayub Ense ${ }^{1}$, Jemmy Charles Kewas ${ }^{2}$, Lenie Ratag ${ }^{3}$ \\ Pendidikan Teknik Mesin Unima, Universitas Negeri Manado \\ ayubense@gmail.com,jemmycharles@unima.ac.id, lenieratag@unima.ac.id
}

\begin{abstract}
ABSTRAK
Penelitian ini bertujuan untuk mengetahui apakah terdapat pengaruh penggunaan model pembelajaran Problem Based Learning terhadap hasil belajar sistem instalasi refrigerasi siswa jurusan teknik pendingin di SMK Negeri 5 Bitung. Jenis penelitian ini merupakan penelitian eksperimen termasuk desain pretest posttes eksperimen dengan menggunakan uji hipotesis, uji normalitas, dan uji t. Yang menjadi populasi pada penelitian ini adalah siswa Jurusan XI pendingin SMK Negeri 5 Bitung yang berjumlah 25 siswa tahun ajaran 2019/2020 semester genap. Yang menjadi sampel penelitian sebanyak 25 siswa tahun ajaran 2019/2020 semester genap. Analisis data gunakan aplikasi SPSS 21. Hasil penelitiaan ini menunjukan ada pengaruh dengan menggunakan model pembelajaran problem based learning terhadap hasil belajar siswa, dengan hitung df $49(\mathrm{n}-1)=2,009$, dapat ditarik kesimpulan bahwa penelitian dengan menggunakan hipotesis rata-rata hitung sebesar $t$ tabel pada kelompok pretest dan posttest eksperimen model pemblajaran problem based learning adalah terdapat peningkatan prestasi belajar siswa kelas XI pendingin SMK Negeri 5 Bitung dengan model penerapan problem based learning.
\end{abstract}

Kata Kunci: Problem Based Learning, Hasil Belajar

\section{ABSTRACT}

This study aims to determine whether there is an effect of using the problem based learning model on the learning outcomes of the refrigeration installation system of students majoring in refrigeration engineering at SMK Negeri 5 Bitung. This type of research is experimental research including pretest posttest experimental design using hypothesis testing, normality test, and t test. The population in this study were students of the XI refrigeration Department at SMK Negeri 5 Bitung, totaling 25 students 2019/2020 school year in the even semester. The research sample was 25 even semester students for academic year the 2019/2020. data analysis using SPSS 21 application. The results of this study indicate that there is an effect using a problem based learning learning model on student learning outcomes, with a count of $d f 49$ (n-1) = 2,009, it can be concluded that the research using the average hypothesis of t table in the pretest group and The experimental posttest of the problem based learning model is that there is an increase in student achievement in class XI cooling at SMK Negeri 5 Bitung with a based learning problem model.

Keywords: Based Learning problem, Learning Outcomes 


\section{PENDAHULUAN}

Based Learning problem merupakan model pembelajaran dengan ciri utamanya yaitu pemecahan masalah oleh para peserta didik yang bertujuan melatih keterampilan memecahkan masalah, berpikir kritis dan memperoleh pengetahuan. (Duck, 1995). Sehingga model pembelajaran Problem Based Learning cocok dipakai dalam berbagai mata pelajaran tanpa terkecuali atau tidak di khususkan untuk satu mata pelajaran saja karena dalam rangka pemecahan masalah yang berhubungan dengan proses pembelajar dan keaktifan siswa dikelas.

Sistem instalasi refrigerasi merupakan salah satu mata pelajaran yang membahas materi tentang komponen - komponen, pemeriksaan performansi unit dan merakit instalasi refrigerasi.

Berdasarkan hasil penelitian penulis yang dilakukan di SMK NEGERI 5 BITUNG, disana terdapat 25 orang siswa, 23 siswa laki-laki dan 2 siswa perempuan. Melihat kenyataan yang sering di hadapi di kelas khususnya kelas XI di SMK, tingkat Pemahaman mengenai mata pelajaran Sistem Instalasi Refrigerasi masih relatif rendah. Hal tersebut menunjukan bahwa banyak siswa yang kurang termotivasi untuk belajar, kurang aktifnya peserta didik untuk menjawab ataupun bertanya tentang materi pembelajaran yang diajarkan. Kemampuan peserta didik dalam penyelesaian soal maupun masalah masih kurang, bahkan guru lebih dominan saat pembelajaran dan siswa lebih pasif. Tidak hanya peserta didik yang kemampuannya kurang saja mengalami hal tersebut, namun peserta didik yang berkemampuan rata-rata dan berkemampuan tinggi juga mengalami hal ini. Hal tersebut mengakibatkan peserta didik mengalami kendala pada saat belajar. Berdasarkan informasi dari guru mengatakan bahwa pada mata pelajaran sistem instalasi refrigerasi kelas XI hasil belajarnya masih kurang.

Nilai rata-rata siswa tahun ajaran 2020/2021 sangatlah rendah yaitu 65, ini belum mencapai kriteria ketuntasan minimum (KKM) yang oleh sekolah adalah ditentukan yaitu 75 . Hal tersebut karena guru hanya menggunakan metode pembelajaran ceramah (konvensional) yaitu guru yang menjadi pusat/center dalam proses pembelajaran dan komunikasi dalam bentuk satu arah. sehingga diperlukanlah suatu sistem pembelajaran yang dapat mendukung proses belajar para siswa.

Berdasarkan uraian di atas maka salah satu upaya yang dapat dilakukan untuk meningkatkan hasil belajar siswa adalah dengan menggunakan model pembelajaran Problem Based Learning.

Menurut Syaiful (2009) pembelajaran adalah proses membelajarkan peserta didik, yang penentu utama keberhasilannya yaitu penggunaan asas-asas pendidikan serta teori belajar. Sedangkan istilah model pembelajaran digunakan untuk mengambarkan proses pembelajaran mulai dari awal sampai akhir. Sehingga model pembelajaran mencerminkan pennggunaan metode, strategi, maupun teknik-teknik pembelajaran.

Menurut Sutarno (2001), belajar adalah suatu proses yang tak hentihentinya dan sangatlah mendasar bagi 
kelangsungan kehidupan manusia. Belajar merupakan proses yang saling berkaitan satu dengan yang lainnya yang mengubah individu dalam berbagai cara. Belajarpun merupakan tindakan perilaku yang kompleks.

\section{Langkah-Langkah Penggunaan Model Problem Based Learning}

Aris S (2014) bependapat bahwa model pembelajaran Problem Based Learning memiliki langkah-langkah sebagai berikut

a. Guru memberikan penjelasan tujuan pembelajaran, hal-hal yang dibutuhkan dalam pembelajaran, serta memberikan dorongan bagi siswa untuk berperan aktif lakukan tuntaskan masalah.

b. Guru membantu siswa untuk mengkelompokkan serta mengartikan tugas dari guru berkaitan dengan masalahan tersbut. (memberikan tugas, topik, jadwal, $\mathrm{dsb})$.

c. guru memotivasi siswa dalam mendapatkan materi sesuai eksperimen supaya peroleh data jelas, jawaban sementara dan pemecah masalah.

d. Guru membantu peserta didik pada proses merancang serta mempersiapkan laporan hasil pemecahan masalah dan membantu siswa untuk membagi tugas dengan rekannya.

Hasil belajar merupakan pencapai oleh peserta didik yang ditunjukkan melalui penguasaan diakhir proses pembelajaran. Hasil belajar adalah perilaku yang dapat berubah oleh adanya proses pembelajaran. Untuk mengetahui seberapa jauh seseorang telah menguasai materi yang sudah ia pelajari, maka sering digunakan hasil belajar untuk mengukurnnya.

Model pembelajaran $P B L$ (ProblemBasedLearning) adalah salah satu pendekatan pembelajaran dimana masalah-masalah yang kongkret digunakan sebagai suatu bahan bagi peserta didik untuk mempelajari bagaimana keterampilan memecahkan masalah dan pola piker yang kritis, juga untuk mendapatkan konsep dan pengetahuan yang bersinergi dengan materi pelajaran dan model $P B L$ memungkin peserta didik untuk memahami dan mengerti suatu aturan maupun konsep-konsep, karena peserta didik mampu menghubungkan kenyataan yang terjadi dengan materi pembelajaran. Dengan ini peserta didik dapat memecahkan masalah dengan berpikir kritis dalam pelajaran Sistem Instalasi Refrigerasi. Olehnya, hasil belajar yang maksimal dapat dicapai peserta didik (Kamdi, 2007).

Menurut Sugiyono

hipotesis atau jawaban sementara, yang telah ditulis dalam bentuk pertanyaan. Maka yang menjadi hipotesis dalam penelitian ini adalah $\mathrm{H}_{\mathrm{O}}$ : Tidak terdapat pengaruh hasil belajar sistem Instalasi Refrigerasi pada siswa kelas XI SMK Negeri 5 Bitung yang pembelajarannya menggunakan Model Pembelajaran Problem Based Learning.

$\mathrm{H}_{1}$ : Terdapat pengaruh hasil belajar Sistem Instalasi Refrigerasi pada siswa kelas XI SMK Negeri 5 Bitung yang proses belajar mengajar menggunakan model pembelajaran ProblemBasedLearning dengan kriteria 
pengujian hipotesis mengikuti syarat dibawah ini Hipotesis diterima apabila $=$ $t t_{\text {hitung }}>t_{\text {tabel }_{\text {tabel }}} ; H_{1}$ diterima dan $H_{O}$ ditolak.

\section{METODE}

Dilihat dari sudut pandang siswa diambil kesimpulan bahwa sifat dan permasalahan penelitian ini merupakan jenis eksperimen. Penelitian eksperimen ini termasuk desain kelompok Kontrol dan Eksperimen (one group class kontrol-eksperimen design).

Penelitian ini akan dilaksanakan pada bulan Juli-september pada semester ganjil tahun ajaran 2020/2021. Adapun penelitian ini yang akan di 1 akukan dengan metode pre-eksperimental melalui jadwal pembelajaran di kelas dengan sistem instalasi refrigerasi pada siswa kelas XI jurusan Teknik Pendingin dan tata udara TPU semester ganjil tahun ajaran 2020/2021.

Menurut Sugiyono

(2009)

populasi merupakan item keseluruhan dari yang akan diteliti terdiri atas objek atau subjek yang oleh peneliti dikaji dan diambil kesimpulannya dari objek-objek yang diteliti. Sehingga populasi adalah keseluruhan objek atau subjek akan diteliti kemudian diolah hasilnya serta ditarik suatu kesimpulan. Dari artian di atas, populasi penelitian ini yaitu keselurhan siswa kelas XI SMK NEGERI 5 BITUNG tahun ajaran 2020/2021.

Dalam pengambilan sampel yang didasarkan oleh pendapat Arikunto (2006) “jika jumlah populasi kurang dari 100, maka ada baiknya semuanya dijadikan sampel. namun apabila jumlah populasi yang diteliti besar atau $>100$ dapat menggunakan sekitar 10-25\% bahkan lebih, disesuaikan dengan tingkat kesulitan jangkauan peneliti.

Dalam penelitian ini menggunakan teknik secara keseluruhan dikarenakan jumlah populasi yang kecil, maka sampel yang diambil berjumlah 25 orang siswa.

\section{HASIL DAN PEMBAHASAN}

Perolehan nilai pre-test dan Posttest dilakukan dengaan menggunakan tindakan one case shot sstudy class, dan untuk hasil nilai pada pre-test dilakukan dengaan menggunakan model pembelajaran konvensional.

Berdasarkan hasil penelitian ini di ambil data dari 25 siswa kelas XI TPU SMK Negeri 5 Bitung. Keadaan sekolah ini dalam sarana prasarana belum terlalu memadai karena masih dalam proses pengembangan sekolah, dilihat dari nilai standar KKM (Kriteria Ketuntasan Minimal) 75,00 pada nilai rata-rata model pembelajaran (PBL) 80,81 > 60.65 pada nilai standar KKM sehingga dapat disimpulkan dengan menggunakan model pembelajaran (PBL) ada pengaruh terhadap hasil belajar siswa. dan untuk mencari nilai yang lebih meningkat pada siswa peniliti melakukan test ekperimen dengan model pembelajaran (PBL).

Sehingga kesimpulannya yaitu dengan model Problem Based Learning (PBL) berpengaruh pada hasil belajar siswa. Dengan hasil model pembelajaran ini dapat dilihat dari aktivitas dalam kelas menjadi positif dan aktif karena adanya ketertarikan modl pembelajaran yang lain yaitu model pembelajaran (PBL) sehingga situasi dalam kelas saling berinteraksi antara siswa dengan 
guru sehingga terjadi aktifitas belajar yang kondusif, aktif, dan interaktif. Beberapa keuntungan penggunaan model pembelajaran (PBL) dalam pembelajaran ini diantaranya: mendorong cara belajar interaktif, mengaktifkan respon siswa atau aktivitas belajar, dan menyediakan sumber belajar yang telah dimodifikasi. Aktivitas belajar adalah salah satu perubahan perilaku sebagai hasil dari belajar (Mc Donough dalam Halimah, 2015).

Hal ini mengindikasikan meningkatnya hasil belajar yang sangat signifikan sebelum dan sesudah dilakukan treatment/perlakuan didasari oleh hasil analisis dengan menggunakan

hasil ujipaired sampel t-Test atau derajat kepercayaan $(\mathrm{dk})=$ nilai $t_{\text {Hitung }}$ $=44,333$ dan $t_{\text {tabel }}=2,009$ jadi $t_{\text {Hitung }}$ $>t_{\text {tabel }}$. Artinya $H_{1}$. Diterima dan $H_{0}$ ditolak.

Jadi peneliti menarik kesimpulan bahwa terdapat pengaruh model pembelajaran Problem Based Learning (PBL) yang signifikan terhadap hasil belajar siswa pada mata pelajaran system instalasi refrigerasi kelas XI di SMK Negeri 5 Bitung.

\section{KESIMPULAN DAN SARAN}

Dari hasil penelitian ini maka di tarik kesimpulan bahwa: Terdapat pengaruh yang signifikan dari pengunaan perlakuan model pembelajaran ProblemBasedLearning terhadap hasil belajar siswa kelas XI TKR SMK Negeri 5 Bitung. Dalam hasil analisis dengan ujipaired sampel t-Test dengan derajat kepercayaan $(\mathrm{dk})=0,05$ nilai $t_{\text {hitung }}=44,333$ dan $t_{\text {tabel }}=2,009$ jadi $t_{\text {hitung }}>t_{\text {tabel }}$. Jadi peneliti menarik kesimpulan bahwa terdapat pengaruh antara model pembelajaran problem based learning terhadap hasil belajar siswa pada mata pelajaran sistem instalasi refrigerasi kelas XI SMK Negeri 5 Bitung.

\section{DAFTAR PUSTAKA}

.Agus S. 2010. Model Pembelajaran. Bandung: Mulia Mandiri Press.

Aris S. 2014. Model Pembelajaran Inovatif dalam K13. Yogyakarta: Ar-Ruz Media

Arismunndar W, Heizo S. 2002. Penyegaran Udara. Jakarta: PTPradnya Paramita

Dosat R, J. 2010. Principle of Refrigeration. Jawa Barat: Universitas Indonesia.

Handoko K. 2009. Teknik Lemari Es. Jakarta: PT. Ichtiar Baru.

Haryanto. 2012. Teknik Mesin Pendingin. Tega: BKPI.

Holman JP. 2011. Perpindahan Panas (Heat Transfer). Jakarta: Erlangga.

Ilyas S. 2010. Teknologi Refrigerasi Hasil Perikanan Jilid I, Badan Peneliti dan Pengembangan Pertanian. Jakarta: CV. Paripurna.

Nurhadi. 2004. The Power of Problem Based Learning.

Nur. 2000. Karakteristik Pembelajaran Problem Based Learning. Jakarta : PT Prestasi Pustakarya.

Syaiful S. 2009. Pembelajaran dan Perkembangan Belajar. Jakarta:

Stoecker WF, Jerol JW. 1994. Refrigerasi dan Pengkondisian Udara Edisi kedua. Jakarta: PT. Erlangga. 
Sumanto. 2001. Dasar - dasar Mesin Pendingin. Yogyakarta: PT Andi

Sanjaya. 2007. Keunggulan dan

Kelemahan Model Pembelajaran
Berbasis Masalah.

Jakarta: PTRinekaCipta.

Sugiyono. 2009. Metode Penelitian

Kuantitatif,Kualitatif dan R\&D.

Bandung:Alfabeta. 